\title{
Analisis Pengaruh PDRB dan Inflasi terhadap Pengangguran Terbuka di Sumatera Utara Periode 2003-2019
}

\author{
Putri Sari M.J. Silaban ${ }^{1)}$, Intan Permata Sari Br Sembiring ${ }^{2)}$, Vini Alvionita Br Sitepu ${ }^{3)}$ \\ 1), 2), 3) Pendidikan Ekonomi Fakultas Ekonomi, Universitas Negeri Medan \\ Email: ellonagultom01@gmail.com ${ }^{l)}$
}

\begin{abstract}
ABSTRAK
Pengangguran merupakan salah satu masalah yang sering dihadapi oleh negara berkembang, salah satunya negara Indonesia. Di Indonesia pengangguran merupakan masalah yang sangat penting untuk diselesaikan, mengingat angka atau besaran tingkat pengangguran yang mengalami kenaikan tiap tahunnya diikuti bertambahnya jumlah penduduk dan jumlah angkatan kerja Indonesia. Indikator-indikator ekonomi yang mempengaruhi tingkat pengangguran antara lain, pertumbuhan ekonomi negara yang bersangkutan, tingkat inflasi, serta besaran upah yang berlaku. Indikator yang dipakai dalam penelitian ini ialah, PDRB ADHB dan inflasi. Penelitian ini bertujuan untuk menganalisis seberapa besar pengaruh PDRB ADHB dan inflasi terhadap pengangguran terbuka di Sumatera Utara periode 2003-2019 baik secara simultan maupun secara parsial. Jenis data yang digunakan dalam penelitian ini adalah data sekunder time series dari tahun 2003 - 2019. Data yang digunakan ialah data yang diperoleh dari website resmi Badan Pusat Statistik (BPS) Sumut. Metode analisis yang digunakan dalam penelitian ini adalah analisis regresi linier berganda dengan software statistika dan ekonometrika Eviews 9. Hasil penelitian menunjukkan bahwa secara parsial Produk Domestik Rill Bruto (PDRB) memiliki pengaruh negatif dan signifikan terhadap pengangguran terbuka di Sumatera Utara pada tahun 2003 -2019 dengan nilai prob sebesar 0,0001<0,05; secara parsial inflasi memiliki pengaruh positif dan tidak signifikan terhadap pengangguran terbuka di Sumatera Utara pada tahun 2003 -2019, dengan nilai prob sebesar 0,3716>0,05. Secara simultan variabel PDRB dan inflasi memiliki pengaruh signifikan terhadap pengangguran di Sumatera Utara pada tahun 2003-2019. Nilai hasil uji R sebesar 77,0674\% dan sisanya sebesar 22,0674\% dipengaruhi oleh faktor lain yang tidak diteliti pada penelitian ini.
\end{abstract}

Kata Kunci: Pengangguran, PDRB, Inflasi

\section{Pendahuluan}

Salah satu permasalahan utama dalam pembangunan ekonomi Negara-negara berkembang yaitu pengangguran. Pengangguran merupakan masalah yang rumit dan lebih serius dari pada masalah perubahan dalam distribusi pemdapatan. Kondisi pembangunan ekonomi negara-negara berkembang dalam beberapa dasawarsa ini tidak sanggup menyediakan kesempatan kerja yang lebih banyak daripada pertambahan penduduk, sehingga masalah pengangguran dari tahun ketahun semakin serius. Apabila hal tersebut terjadi dan tidak segera diatasi dan dicari jalan keluarnya, maka dapat menimbulkan kerawanan social dan berpotensi menambah tingkat kemiskinan (Siswosoemarto, 2012).

Kompleksitas permasalahan pengangguran memang perlu untuk dibahas dan merupakan isi penting, karena dapat dikaitkan dengan beberapa indikator-indikator. Indikator-indikator ekonomi yang mempengaruhi tingkat pengangguran antara lain pertumbuhan ekonomi Negara yang bersangkutan, tingkat inflasi, serta besaran upah yang berlaku. Apabila di suatu Negara pertumbuhan ekonominya mengalami kenaikan, diharapkan akan berpengaruh pada penurunan jumlah pengangguran, hal ini diikuti dengan tingkat upah. Jika tingkat upah naik akan berpengaruh pada penurunan jumlah pengangguran pula. Sedangkan tingkat inflasi yang tinggi akan berpengaruh pada kenaikan jumlah pengangguran (Sukirno, 2008).
Provinsi Sumatera Utara yang memiliki jumlah penduduk berkisar 14,8 juta jiwa pada tahun 2020 ini adalah salah satu Provinsi yang berperan penting bagi kemajuan Perekonomian Indonesia dengan ibu kotanya sebagai kota terbesar ketiga di Indonesia setelah Jakarta dan Surabaya.Karena berhasil memberikan sumbangsih terhadap ekonomi Indonesia dari berbagai sektornya. Namun meski begitu ternyata angka pengganguran di Sumatera Utara masih terbilang tinggi. Hal ini dibuktikan dengan data dari Badan Pusat Statistik (BPS) pada tahun 2019 yang mencatat bahwa adanya peningkatan angka pengganguran terbuka di Sumatera Utara sebesar 5,56 persen dari partisipasi angkatan kerja dan jumlah pengangguran ini diprediksi akan terus meningkat jika masalah ini tidak segera diatasi.

Salah satu indikator tingkat kesejahteraan penduduk suatu wilayah adalah angka PDRB. PDRB adalah nilai bersih barang dan jasa-jasa akhir yang dihasilkan oleh berbagai kegiatan ekonomi si suatu wilayah dalam suatu periode (Sukmaraga, 2011). PDRB mempunyai pengaruh terhadap jumlah angkatan kerja yang bekerja dengan asumsi apabila nilai PDRB meningkat, maka jumlah nilai tambah barang dan jasa dalam seluruh unit ekonomi di suatu wilayah akan meningkat. Barang dan jasa yang jumlahnya meningkat tersebut akan menyebabkan terjadinya peningkatan terhadap jumlah tenaga kerja yang diminta. Produk Domestik Regional Bruto (PDRB) atas harga konstan digunakan untuk menunjukkan laju 
pertumbuhan ekonomi secara keseluruhan dari tahun ke tahun.

Indikator selanjutnya yang mempengaruhi tingkat pengangguran adalah inflasi. Menurut Sukirno (2004) inflasi merupakan suatu proses kenaikan harga-harga yang berlaku dalam suatu perekonomian. Sedangkan tingkat inflasi adalah presentasi kenaikan harga-harga barang dalam periode waktu tertentu. Kondisi perekonomian dengan tingkat inflasi yang tinggi dapat menyebabkan perubahanperubahan output dan kesempatan kerja. Apabila tingkat inflasi meningkat, maka maka harga-harga barang dan jasa juga akan naik, selanjutnya permintaan - permintaan akan barang dan jasa akan turun dan akan mengurangi permintaan terhadap tenaga kerja yang dibutuhkan, akibatnya akan meningkatkan jumlah pengangguran terbuka.

Tingkat inflasi juga menjadi salah satu penentu dari tingkat pengangguran. Inflasi adalah gejala yang menunjukkan kenaikan tingkat harga umum yang berlangsung terus menerus. Dari pengertian tersebut maka apabila terjadi kenaikan harga hanya bersifat sementara, maka kenaikan harga yang sementara sifatnya tersebut tidak dapat dikatakan inflasi. Semua negara di dunia selalu menghadapi permasalahan inflasi ini. Oleh karena itu, tingkat inflasi yang terjadi dalam suatu negara merupakan salah satu ukuran untuk mengukur baik buruknya masalah ekonomi yang dihadapi suatu negara.

Berdasarkan penjelasan di atas, maka rumusan masalah pada penelitian ini adalah sebagai berikut: (1) Apakah ada pengaruh PDRB ADHB terhadap tingkat pengangguran di Sumatera Utara periode 2003- 2019; (2) Apakah ada pengaruh inflasi terhadap tingkat pengangguran di Sumatera Utara periode 2003- 2019?; (3) Apakah ada pengaruh PDRB ADHB dan inflasi secara simultan terhadap pengangguran di Sumatera Utara periode 2003- 2019?

\section{Landasan Teori \\ Produk Domestik Regional Bruto (PDRB)}

Produk Domestik Regional Bruto (PDRB) adalah indikator ekonomi makro yang dapat memberikan gambaran tentang keadaan perekonomian suatu wilayah. Di dalam menghitung Produk Domestik Regional Bruto (PDRB) yang di timbulkan dari suatu region, ada 3 pendekatan yang digunakan yaitu: 1. PDRB menurut pendekatan produksi Merupakan jumlah nilai barang atau jasa akhir yang dihasilkan oleh berbagai unit produksi yang berada di suatu wilayah dalam jangka waktu tertentu; 2. PDRB menurut pendekatan pendapatan Merupakan balas jasa yang digunakan oleh faktor-faktor produksi yang ikut serta dalam proses produksi di suatu wilayah dalam waktu tertentu; 3. PDRB menurut pendekatan pengeluaran Merupakan semua komponen pengeluaran akhir seperti: pengeluaran konsumsi rumah tangga dan lembaga swasta nirlaba, konsumsi pemerintah, pembentukan modal tetap bruto, perubahan stok dan ekspor neto dalam jangka waktu tertentu (Prishardoyo, 2008).

\section{Teori Basis Ekonomi (Economic Base Theory)}

Teori basis ekonomi ini dikemukakan oleh Harry W. Richardson yang menyatakan bahwa faktor penentu utama pertumbuhan ekonomi suatu daerah adalah berhubungan langsung dengan permintaan akan barang dan jasa dari luar daerah. Dalam teori basis ekonomi (economic base) bahwa semua wilayah merupakan sebuah sistem sosio ekonomi yang terpadu. Teori inilah yang mendasari pemikiran teknik location quotient, yaitu teknik yang membantu dalam menentukan kapasitas ekspor perekonomian daerah dan derajat keswasembada (self-sufficiency) suatu sektor. Menurut Glasson, konsep dasar basis ekonomi membagi perekonomian menjadi dua sektor yaitu: a. Sektor-sektor basis adalah sektor-sektor yang mengekspor barang-barang dan jasa ke tempat di luar batas perekonomian masyarakat yang bersangkutan. b. Sektor-sektor bukan basis adalah sektor-sektor yang menjadikan barang-barang yang dibutuhkan oleh orang yang bertempat tinggal di dalam batas perekonomian masyarakat bersangkutan (Prishardoyo, 2008).

\section{Inflasi}

Inflasi merupakan kecenderungan kenaikan hargaharga umum secara terus menerus (Rumbiati, 2016; DP, 2017; Royda \& Seto, 2018; Ulum, 2019). Dari defenisi ini dapat dikatakan bahwa kenaikan satu atau beberapa pada suatu saat tertentu dan hanya "sementara" belum tentu menimbulkan inflasi (Munandar, 2017; Saputra, Isnurhadi, \& Romli, 2019). Gejala kenaikan umum yang cepat atau tinggi selama periode waktu tertentu disebut keadaan inflasi (Prasetyo, 2009). Angka inflasi sebagai salah satu indikator stabilitas ekonomi selalu menjadi pusat perhatian orang, paling tidak turunya angka inflasi mencerminkan gejolak ekonomi di suatu negara. Dalam ilmu ekonomi, inflasi adalah suatu proses meningkatnya harga- harga secara umum dan terus-menerus (kontinu) berkaitan dengan mekanisme pasar yang dapat disebabkan oleh berbagai faktor, antara lain, konsumsi masyarakat yang meningkat, berlebihnya likuiditas di pasar yang memicu konsumsi atau bahkan spekulasi, sampai termasuk juga akibat adanya ketidak lancaran distribusi barang. Ada banyak cara untuk mengukur tingkat inflasi, dua yang paling sering digunakan adalah CPI dan GDP Delfator. Inflasi dapat digolongkan menjadi empat golongan, yaitu: Inflasi ringan (kurang dari $10 \%$ /tahun), inflasi sedang (antara 10\% sampai $30 \% /$ tahun), inflasi berat (antara 30\% sampai 100\%/tahun), hiperinflasi (lebih dari 100\%/tahun).

\section{Pengangguran Terbuka}

Pengangguran terbuka tercipta sebagai akibat pertambahan lowongan pekerjaan yang lebih rendah dari pertambahan tenaga kerja. Sebagai akibat dalam perekonomian semakin banyak jumlah tenaga kerja yang tidak dapat memperoleh pekerjaan. Efek dari keadaan ini didalam suatu jangka masa yang cukup panjang mereka tidak melakukan sesuatu pekerjaan. Jadi, mereka menganggur secara nyata dan sepenuh waktu dan oleh karenanya dinamakan pengangguran terbuka. Pengangguran terbuka dapat pula wujud sebagai akibat 
dari kegiatan ekonomi yang menurun, dari kemajuan teknologi yang mengurangi penggunaan tenaga kerja, atau sebagai akibat dari kemunduran perkembangan sesuatu industri (Sukirno, 2004). Pengangguran terbuka (open unemployment) adalah mereka yang benar-benar sedang tidak bekerja baik secara sukarela (orang-orang yang sebenarnya bisa saja memperoleh suatu pekerjaan permanen Namun karena alasan-alasan tertentu misalnya karena mereka sudah cukup Makmur tanpa bekerja, mereka tidak mau memanfaatkan kesempatan kerja yang tersedia) maupun karena terpaksa (mereka yang sesungguhnya sangat ingin bekerja secara permanen namun tidak kunjung mendapatkan) (Nanga, 2001).

Untuk menghitung pengangguran terbuka k-dha part menggunakan rumus sebagai berikut:

$T P T=($ pencari kerja:angkatan kerja) $\times 100 \%$

\section{Hasil Penelitian Terdahulu}

Berdasarkan penelitian tang telah dilakukan oleh (Soekarnoto.2014) dengan judul penelitian "Pengaruh PDRB, UMK, Inflasi, dan Investasi Terhadap Pengangguran Terbuka di Kab/ Kota Provinsi Jawa Timur Tahun 2007-2011" menunjukkan bahwa variabel PDRB mempunyai hubungan negatif dan berpengaruh signifikan terhadap tingkat pengangguran terbuka di kab/ kota di Provinsi Jawa Timur pada tahun 2007-2011. Selain itu berdasarkan penelitian yang dilakukan oleh (laksamana. 2016) dengan judul penelitian pengaruh PDRB terhadap pengangguran di kabupaten/ kota Kalimantan Barat menunjukkan bahwa pdrb berpengaruh negatif dan signifikan terhadap pengangguran di Kalimantan Barat.

Pada penelitian yang dilakukan oleh (Soekarnoto. 2014) tentang "Pengaruh PDRB, UMK, Inflasi, dan Investasi Terhadap Pengangguran Terbuka di Kab/ Kota Provinsi Jawa Timur Tahun 2007-2011" juga menyatakan bahwa variabel "inflasi mempunyai hubungan positif dan tidak berpengaruh signifikan terhadap tingkat pengangguran terbuka di Kab/Kota Provinsi Jawa Timur tahun 2007 - 2011". Kemudian berdasarkan penelitian yang dilakukan oleh (Kuntiarti. 2018) dengan judul penelitian "Pengaruh inflasi, jumlah penduduk dan kenaikan upah minimum terhadap pengangguran terbuka di Provinsi Banten tahun 2010- 2015" menunjukkan hasil penelitian bahwa inflasi berpengaruh tidak signifikan terhadap pengangguran di Provinsi Banten.

\section{Metodologi}

Data Penelitian ini merupakan data sekunder perhitungan tahunan (yearly) dari tahun 2003-2019, jenis data yang digunakan dalam analisis ini yaitu data berskala (time series data). populasi yang digunakan adalah datadata yang ada di Sumatera Utara, meliputi Pengangguran, PDRB, dan Inflasi periode 2003-2019.

\section{Data}

Data yang digunakan untuk mencapai tujuan dalam penelitian ini sepenuhnya diperoleh melalui Badan Pusat Statistic Sumatera Utara dalam bentuk SUDA (Sumatera Utara Dalam Angka) serta bentuk-bentuk lain yang dikeluarkan oleh BPS Sumut periode 2003-2019 yang di akses melalui internet.

\section{Metode Analisis}

Dalam penelitian ini mengguakan analisis kuantitatif yaitu merupakan analisis yang menggunakan alat perhitungan statistik. Untuk mengetahui hubungan antar variabel penelitian ini menggunakan alat regresi linear berganda. Regresi linier berganda digunakan untuk menganalisis hubungan antar variabel terikat dengan variabel bebas. Dalam pengelolaan data digunakan software dalam komputer yaitu berupa Eviews 9. Secara sistematis dirumuskan sebagai berikut:

\section{Pengangguran $=C+\beta_{1} P D R B+\beta_{2}$ Inflasi}

\section{Teknik Pengumpulan Data}

Data yang digunakan untuk mencapai tujuan dalam penelitian ini sepenuhnya diperoleh melalui Badan Pusat Statistic Sumatera Utara dalam bentuk SUDA (Sumatera Utara Dalam Angka) serta bentuk-bentuk lain yang dikeluarkan oleh BPS Sumut periode 2003 - 2019 yang di akses melalui internet.

\section{Pembahasan \\ Model Regresi Linier Berganda}

Hasil analisis regresi linier berganda untuk menguji pengaruh PDRB ADHB dan Inflasi terhadap Pengangguran di Sumatera Utara Tahun 2003-2019, disajikan pada tabel berikut:

Tabel 1. Hasil Uji Regresi Berganda

\begin{tabular}{|l|l|l|l|l|}
\hline \multicolumn{2}{|l|}{ Dependent Variable: Log_Y } & & \\
\hline Method: Least Squares & & \\
\hline Variable & Coefficient & Std. Error & t-Statistic & Prob. \\
\hline C & 2.677066 & 0.359023 & 7.456535 & 0.0000 \\
\hline Log_X1 & -0.334317 & 0.061020 & -5.478779 & 0.0001 \\
\hline Log_X2 & 0.055865 & 0.060520 & 0.923088 & 0.3716 \\
\hline
\end{tabular}

Berdasarkan Tabel 1 terdapat dua variabel bebas yaitu variabel PDRB ADHB dan Inflasi sehingga diperoleh persamaan regresi linier berganda sebagai berikut:

$$
Y=2,677066-0,334317 X_{1}+0,055865 X 2
$$

Persamaan regresi tersebut dapat dijelaskan sebagai berikut:

1. Nilai konstanta (a) sebesar 2,677066, artinya jika PDRB ADHB(X1) dan Inflasi (X2) nilainya adalah 0, maka nilai Pengangguran (Y) adalah 2,677066;

2. Nilai koefisien regresi variabel PDRB (X1) sebesar 0,334317 , artinya jika variabel bebas lain nilainya tetap dan PDRB mengalami kenaikan 1 persen, Pengangguran (Y) akan mengalami penurunan sebesar 0,334317 persen dengan asumsi variabel bebas lain nilainya tetap. Koefisien bernilai negatif artinya terjadi hubungan negatif antara PDRB ADHB dengan Pengangguran, semakin tinggi nilai PDRB maka semakin rendah jumlah orang yang menganggur; 
3. Nilai koefisien regresi variabel Inflasi (X2) sebesar 0,055865 , yang artinya bahwa setiap penambahan 1 persen nilai inflasi maka akan menaikkan jumlah orang yang menganggur sebesar 0,055865 persen dengan asumsi bahwa variabel bebas lain tetap. Koefisien bernilai positif artinya terjadi hubungan positif antara inflasi dengan pengangguran, semakin tinggi inflasi maka semakin tinggi pula jumlah orang yang menganggur.

\section{Uji Asumsi Klasik \\ Uji Normalitas}

Tabel 2. Histogram/Normality Test

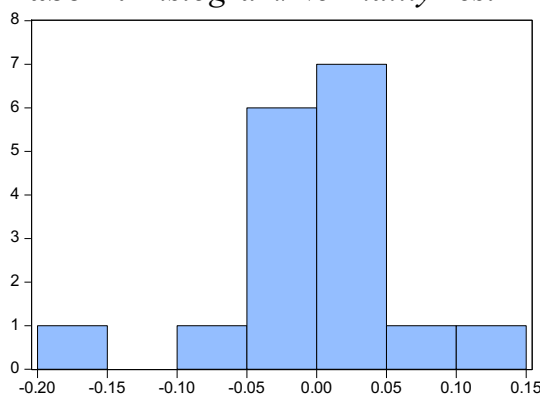

\begin{tabular}{|c|c|}
\hline \multicolumn{2}{|c|}{$\begin{array}{l}\text { Series: Residuals } \\
\text { Sample } 20032019 \\
\text { Observations } 17\end{array}$} \\
\hline Mean & $-1.93 \mathrm{e}-16$ \\
\hline & \\
\hline um & 0.11 \\
\hline Minim & -0.151 \\
\hline & \\
\hline Skewness & -0.57851 \\
\hline Kurtosis & 4.09847 \\
\hline & \\
\hline Probability & \\
\hline
\end{tabular}

Berdasarkan Tabel 2 diatas diketahui bahwa nilai probability $>0,05$ yang artinya bahwa data pada penelitian ini berdistribusi normal.

\section{Uji Autokorelasi}

Tabel 3. Hasil Uji Dw

\begin{tabular}{|l|l|}
\hline $\begin{array}{l}\text { Dependent Variable: Log_Y } \\
\text { Method: Least Squares }\end{array}$ \\
\hline Durbin-Watson stat & 1.840152 \\
\hline
\end{tabular}

Berdasarkan output eviews diperoleh nilai Dw seperti pada Tabel 3 diatas, nilai Dw tersebut berada diantara 1.54 dan 2.46 yaitu 1.840152 yang memiliki arti bahwa data pada penelitian ini tidak memiliki masalah autokorelasi.

\section{Uji Multikolinearitas}

Tabel 4. Variance Inflation Factors

\begin{tabular}{|l|l|l|l|}
\hline \multicolumn{2}{|l|}{ Variance Inflation Factors } & \\
\hline & Coefficient & Uncentered & Centered \\
\hline Variable & Variance & VIF & VIF \\
\hline C & 0.128897 & 550.1679 & NA \\
\hline Log_X1 & 0.003723 & 482.0965 & 1.313758 \\
\hline Log_X2 & 0.003663 & 9.265547 & 1.313758 \\
\hline
\end{tabular}

Berdasarkan Tabel 4 diatas dapat kita lihat bahwa nilai VIF dari variabel bebas penelitian ini $<10$ yang artinya tidak ada masalah multikolinearitas pada data ini.

\section{Uji Regresi \\ Uji koefisien Determinasi $\mathbf{R}^{2}$}

Berdasarkan tabel 5 diatas diperoleh nilai R-squared sebesar 0.770674 yang artinya bahwa variabel PDRB
ADHB dan inflasi mampu mempengaruhi pengangguran di provinsi Sumatera Utara pada tahun 2003- 2019 sebesar $77,0674 \%$ dan sisanya sebesar 22,0674\% dipengaruhi oleh faktor lain yang tidak diteliti pada penelitian ini.

Tabel 5. Hasil Uji Koefisien Determinasi

\begin{tabular}{|l|l|}
\hline \multicolumn{2}{|l|}{ Dependent Variable: Log_Y } \\
\hline Method: Least Squares \\
\hline R-squared & 0.770674 \\
\hline Adjusted R-squared & 0.737913 \\
\hline
\end{tabular}

Uji F

Tabel 6. Hasil Uji $F$

Dependent Variable: Log_Y Method: Least Squares

\begin{tabular}{|l|l|}
\hline F-statistic & 23.52426 \\
\hline Prob(F-statistic) & 0.000033 \\
\hline
\end{tabular}

Berdasarkan hasil olah data diperoleh nilai Prob (Fstatistic) seperti pada Tabel 6 diatas yaitu sebesar $0.000033<0,05$ yang artinya secara simultan variabel PDRB ADHB dan inflasi berpengaruh signifikan terhadap pengangguran di Sumatera Utara pada tahun 2003- 2019. Hasil uji F dalam penelitian ini juga sejalan dengan hasil penelitian sebelumnya yang dilakukan oleh Nur Fitri Yanti (2019). dengan judul "Analisis Pengaruh Inflasi, Investasi, dan PDRB terhadap tingkat Pengangguran di Wilayah Sulawesi Periode 2010-2014" yang menyatakan bahwa variabel independen secara serempak berpengaruh signifikan terhadap variabel dependen.

Hasil ini juga didukung oleh penelitian sebelumnya Soekarno (2014) dengan judul "Pengaruh PDRB, UMK, Inflasi,dan Investasi Terhadap Pengangguran Terbuka di Kab/ Kota Provinsi Jawa Timur Tahun 2007-2011" yang menunjukkan bahwa variabel PDRB dan Inflasi secara simultan berpengaruh signifikan terhadap tingkat pengangguran terbuka di $\mathrm{kab} /$ kota di Provinsi Jawa Timur.

\section{Uji t}

Tabel 7. Hasil Uji $t$

\begin{tabular}{|c|c|c|l|c|}
\hline \multicolumn{2}{|c|}{ Dependent Variable: Log_Y } & & \\
\hline \multicolumn{2}{|c|}{ Method: Least Squares } & & \\
\hline $\begin{array}{c}\text { Variabl } \\
\mathrm{e}\end{array}$ & $\begin{array}{c}\text { Coefficien } \\
\mathrm{t}\end{array}$ & $\begin{array}{c}\text { Std. } \\
\text { Error }\end{array}$ & t-Statistic & Prob. \\
\hline $\mathrm{C}$ & 2.677066 & $\begin{array}{c}0.35902 \\
3\end{array}$ & 7.456535 & $\begin{array}{c}0.000 \\
0\end{array}$ \\
\hline $\begin{array}{c}\text { Log_X } \\
1\end{array}$ & -0.334317 & 0.06102 & -5.478779 & 0.000 \\
& & 0 & & 1 \\
\hline $\begin{array}{c}\text { Log_X } \\
2\end{array}$ & 0.055865 & 0.06052 & 0.923088 & 0.371 \\
& & 0 & & 6 \\
\hline
\end{tabular}

Hasil pengolahan data diatas dapat disimpulkan sebagai berikut:

1. Pengaruh Produk Domestik Bruto terhadap Tingkat Pengangguran Terbuka di Provinsi Sumatera Utara tahun 2003-2019.

Berdasarkan hasil analisis regresi linier berganda 
diperoleh nilai koefisien regresi variabel PDRB (X1) sebesar -0,334317, artinya jika variabel bebas lain nilainya tetap dan PDRB mengalami kenaikan 1 persen, Pengangguran (Y) akan mengalami penurunan sebesar 0,334317 persen dengan asumsi variabel bebas lain nilainya tetap. Koefisien bernilai negatif artinya terjadi hubungan negatif antara PDRB ADHB dengan Pengangguran, semakin tinggi nilai PDRB maka semakin rendah jumlah orang yang menganggur. Secara parsial variabel X1 berpengaruh negatif dan signifikan terhadap pengangguran di Sumatera Utara pada tahun 2003-2019 dengan nilai prob sebesar $0,0001<0,05$.

Penelitian ini sesuai dengan penelitian yang dilakukan oleh Soekarno (2014) dengan judul "Pengaruh PDRB, UMK, Inflasi,dan Investasi Terhadap Pengangguran Terbuka di Kab/ Kota Provinsi Jawa Timur Tahun 2007-2011" yang menunjukkan bahwa variabel PDRB mempunyai hubungan negatif dan berpengaruh signifikan terhadap tingkat pengangguran terbuka di kab/ kota di Provinsi Jawa Timur. Penelitian ini juga didukung dengan penelitian yang dilakukan sebelumnya oleh Dian Priastiwi (2019) dengan judul "Analisis Pengaruh Jumlah Penduduk, Pendidikan, Upah Minimum, dan PDRB Terhadap Tingkat Pengganguran Terbuka di Provinsi Jawa Tengah" yang menunjukkan bahwa variabel PDRB berpengaruh signifikan dengan pengaruh negatif terhadap tingkat pengganguran terbuka. Artinya peningkatan PDRB akan mengurangi pengganguran.

2. Pengaruh Inflasi terhadap Tingkat Pengangguran Terbuka di Provinsi Sumatera Utara tahun 2003-2019. Berdasarkan hasil analisis regresi linier berganda diperoleh nilai koefisien regresi variabel Inflasi (X2) sebesar 0,055865, yang artinya bahwa setiap penambahan 1 persen nilai inflasi maka akan menaikkan jumlah orang yang menganggur sebesar 0,055865 persen dengan asumsi bahwa variabel bebas lain tetap. Koefisien bernilai positif artinya terjadi hubungan positif antara inflasi dengan pengangguran, semakin tinggi inflasi maka semakin tinggi pula jumlah orang yang menganggur.

Secara parsial variabel X2 berpengaruh positif dan tidak signifikan terhadap pengangguran di Sumatera Utara pada tahun 2003- 2019 dengan nilai prob sebesar 0,3716 $>0,05$. Penelitian ini juga didukung dengan penelitian yang dilakukan sebelumnya oleh Warda Harahap, dengan judul "Inflasi, Pertumbuhan Ekonomi dan Upah terhadap Pengganguran Terdidik di Indonesia" yang menunjukkan bahwa variabel Inflasi berpengaruh tidak signifikan dengan pengaruh positif terhadap tingkat pengganguran terdidik. Selain itu penelitian ini juga sejalan dengan penelitian sebelumnya yang dilakukan oleh Siti Delvi Janiarti dengan judul "Analisis Pengaruh Inflasi, Investasi dan Pertumbuhan Ekonomi terhadap Pengganguran di Indonesia Periode tahun 2002-2015" yang menunjukkan bahwa laju inflasi berpengaruh positif tidak signifikan terhadap pengganguran di Indonesia.

\section{Kesimpulan}

Dari hasil penelitian diatas penulis menarik kesimpulan bahwa:

1. Secara parsial Produk Domestik Rill Bruto memiliki pengaruh negatif dan signifikan terhadap Kemiskinan di Sumatera Utara pada tahun 2003- 2019, artinya setiap peningkatan PDRB akan menurunkan tingkat pengangguran terbuka di Provinsi Sumatera Utara pada tahun 2003-2019.

2. Secara parsial Inflasi memiliki pengaruh positif dan tidak signifikan terhadap pengangguran di Sumatera Utara pada tahun 2003- 2019, artinya setiap terjadi peningkatan inflasi maka akan meningkatkan jumlah pengangguran di Provinsi Sumatera Utara tahun 20032019 namun tidak signifikan.

3. Secara simultan variabel Produk Domestik Rill Bruto dan Inflasi memiliki pengaruh signifikan terhadap pengangguran di Sumatera Utara pada tahun 20032019

4. Hasil penelitian ini menunjukkan bahwa variabel yang signifikan dan paling dominan terhadap pengangguran di Sumatera Utara pada tahun 2003- 2019 adalah PDRB.

\section{Saran}

1. Pemerintah harus meningkatkan PDRB di Sumatera Utara, misalnya dengan meningkatkan sektor pariwisata;

2. Pemerintah harus mampu untuk menjaga kestabilan inflasi;

3. Untuk peneliti yang akan datang supaya dapat menambah variabel penelitiannya.

\section{Daftar Pustaka}

Badan Pusat Statistik. (2018). Sumatera Utara Dalam Angka 2018. Provinsi Sumatera Utara : Badan Pusat Statistik Sumatera Utara https://sumut.bps.go.id/publication/2018/08/16/6bb 0847a56d2c3a34cf860b7/provinsi-sumatera-utaradalam-angka-2018.html

Badan Pusat Statistik. (2019). Sumatera Utara Dalam Angka 2019. Provinsi Sumatera Utara : Badan Pusat Statistik Sumatera Utara https://sumut.bps.go.id/publication/2019/08/16/2de 0bed06bc3128c5e96007e/provinsi-sumatera-utaradalam-angka-2019.html

Badan Pusat Statistik. (2003 s/d 2017). Sumatera Utara Dalam Angka (2003 s/d 2017). Provinsi Sumatera Utara: Badan Pusat Statistik Sumatera Utara

Dharmayanti, Yeny. 2011. Analisis Pengaruh PDRB, Upah dan Inflasi terhadap pengangguran Terbuka di Provinsi Jawa Tengah Tahun 1991-2009. Universitas Diponegoro, Semarang.

DP, M. K. (2017). Analisis Faktor-Faktor Penyebab Kemiskinan Di Kabupaten Musi Banyuasin (Studikasus Di Kecamatan Sungai Lilin). Jurnal Ilmiah Ekonomi Global Masa Kini, 8(1), 16-20.

Kuntiarti, 2018. Pengaruh inflasi, jumlah penduduk dan kenaikan upah minimum terhadap pengangguran 
terbuka di Provinsi Banten tahun 2010- 2015. Jurnal pendidikan dan ekonomi, Volume 7, Nomor 1, Tahun 2018.

Laksamana, 2016. Pengaruh PDRB terhadap pengangguran di kabupaten/kota Kalimantan Barat. Jurnal audit dan akuntansi fakultas ekonomi dan bisnis Universitas Tanjungpura. Vol. 5, No. 2, Desember 2016 Hal 111- 134.

Munandar, A. (2017). Analisis Regresi Data Panel Pada Pertumbuhan Ekonomi Di Negara-Negara Asia. Jurnal Ilmiah Ekonomi Global Masa Kini, 8(1), 5967.

Nanga, muana. 2001. Makroekonomi: teori, masalah dan kebijakan. Edisi 1. Jakarta: PT Raja Grafindo Persada.

Prastyo, P.E (2009). Fundamental makro ekonomi. Beta offset: Yogyakarta.

Prishardoyo, Bambang. 2008. Analisis Tingkat Pertumbuhan Ekonomi Dan Potensi Ekonomi Terhadap Produk Domestik Regional Bruto (PDRB) Kabupaten Pati Tahun 2000-2005. Vol. 1, no. 1.

Royda, R., \& Seto, A. A. (2018). Pengaruh Upah Terhadap Produktifitas dan Inflasi Pada Sektor Industri Manufaktur di Kota Palembang. Jurnal Ilmiah Ekonomi Global Masa Kini, 9(1), 15-20.

Rumbiati, R. (2016). PENGARUH INFLASI DAN NILAI TUKAR TERHADAP PERGERAKAN INDEKS HARGA SAHAM GABUNGAN DI BURSA EFEK INDONESIA (PERIODE JANUARI 2010-DESEMBER 2015). Jurnal Ilmiah Ekonomi Global Masa Kini, 7(2), 52-61.

Saputra, T. S., Isnurhadi, I., \& Romli, H. (2019). Pengaruh Inflasi Terhadap Tingkat Piutang Bermasalah (Non Performing Loan) Perusahaan Pembiayaan di Kota Palembang. Jurnal Ilmiah Ekonomi Global Masa Kini, 10(2), 99-102.

Siswosoemarto, Rubijianto. 2012. Intelijen Ekonomi: Teori dan Aplikasi. Jakarta: PT. gramedia Pustaka Utama.

Soekarnoto, 2014. Pengaruh PDRB, UMK, Inflasi,dan Investasi Terhadap Pengangguran Terbuka di Kab/ Kota Provinsi Jawa Timur Tahun 2007-2011. Jurnal Ekonomi dan Bisnis. Tahun XXIV, No.2 Agustus 2014.

Sukirno, Sadono. 2004. Makroekonomi Teori Pengantar. Edisi ketiga. Jakarta: PT Raja Grafindo Persada.

Sukirno, Sadono. 2008. Makro Ekonomi Teori Pengantar. Edisi Ketiga. Jakarta: raja Grafindo Persada.

Sukmaraga, Prima. 2011. Analisis Pengaruh Indeks Pembangunan Manusia, PDRB per Kapita dan Jumlah Pengangguran Terhadap Jumlah Penduduk Miskin di Provinsi Jawa Tengah. Universitas Diponegoro, Semarang.Format Penulisan.

Ulum, M. B. (2019). Analisis Pengaruh Jumlah Nasabah, Tingkat Inflasi, dan Profit Pegadaian Syariah terhadap Jumlah Pembiayaan pada PT. Pegadaian (Persero) Cabang Syariah Kota Palembang. Jurnal Ilmiah Ekonomi Global Masa Kini, 10(1), 21-24. 